\title{
Occurrence of Philometra lateolabracis (Nematoda: Philometridae) in the gonads of marine perciform fishes in the Mediterranean region
}

\author{
František Moravec $^{1, *}$, Branko Glamuzina ${ }^{2}$, Giovanna Marino ${ }^{3}$, Paolo Merella ${ }^{4}$, David Di Cave ${ }^{5}$ \\ ${ }^{1}$ Institute of Parasitology, Academy of Sciences of the Czech Republic, Branišovská 31, 37005 České Budějovice, Czech Republic \\ ${ }^{2}$ Institute of Oceanography and Fisheries, POB 83, 20000 Dubrovnik, Croatia \\ ${ }^{3}$ Istituto Centrale per la Ricerca Scientifica e Tecnologica Applicata al Mare (ICRAM), Via di Casalotti 300, 00166 Rome, Italy \\ ${ }^{4}$ Dipartimento di Biologia Animale, Università di Sassari, Via Vienna 2, 07100 Sassari, Italy \\ ${ }^{5}$ Dipartimento di Sanità Pubblica e Biologia Cellulare, Università degli Studi di Roma 'Tor Vergata', Via Montpellier 1, 00173 Rome, Italy
}

\begin{abstract}
Gravid females of the nematode Philometra lateolabracis (Yamaguti, 1935), a parasite of gonads of marine perciform fishes, were found in wild and cultured dusky grouper Epinephelus marginatus (Lowe) from waters near the Balear Islands (Spain, Mediterranean Sea) and Sicily (Italy, Thyrrenean Sea), and in the greater amberjack Seriola dumerili (Risso) in Croatia (south-eastern Adriatic Sea). In wild E. marginatus in Spain, the overall prevalence was $21 \%$ and the intensity of infection 1 nematode per fish. The nematodes are briefly described and illustrated. The species Sanguinofilaria jordanoi López-Neyra, 1951, described from the ovary of Epinephelus gigas Brünich from Morocco, is synonymized with $P$. lateolabracis. This is the first documented record of $P$. lateolabracis from fishes of the Mediterranean region and its finding in $S$. dumerili represents a new host record. The possible importance of this pathogenic parasite for cultures of marine perciform fishes in the region is stressed.
\end{abstract}

KEY WORDS: Parasitic nematode $\cdot$ Philometra lateolabracis Tissue parasite $\cdot$ Marine fish $\cdot$ Epinephelus marginatus $\cdot$ Seriola dumerili $\cdot$ Mediterranean region $\cdot$ Spain $\cdot$ Italy $\cdot$ Croatia

Resale or republication not permitted without written consent of the publisher

Nematodes of the family Philometridae Baylis et Daubney, 1926 are frequent parasites of the abdominal cavity and various body tissues of freshwater and marine fishes. Most species are known only from the large-sized gravid females, whereas the minute males of many species and genera have not yet been described (Moravec et al. 1998).

During recent years, particularly in connection with the quickly developing cultures of marine fishes, increasing attention has been paid to studies on the philometrid nematodes parasitizing fish gonads.
Heavy infections by these parasites have been recorded in many species of marine, mainly perciform, fishes of economic importance, both free-living and cultured. The large-sized females of these nematodes are usually highly pathogenic, causing serious damage to the fish ovaries, and may thus affect fish reproduction (Ramachandran 1975, Sakaguchi et al. 1987, Moravec et al. 1997, 2002). Although species parasitic in fish gonads are widely distributed, to our knowledge mainly in the tropical and subtropical regions of the Pacific, Indian and Atlantic Oceans, these nematodes have so far been reported neither from the Mediterranean region nor from other European waters.

Recent parasitological examinations of some marine perciform fishes in the Mediterranean region revealed the presence of Philometra female specimens in the gonads of the wild dusky grouper Epinephelus marginatus (Lowe, 1834) (family Serranidae, Perciformes) off the Balearic Islands, Spain (Mediterranean Sea) and of wild and cultured E. marginatus off Sicily, Italy (Thyrrenean Sea). Of 14 Spanish localities, the parasite was recorded from fishes in 5 localities (Alcudia, Cabrera, Cala Ratjada, Columbretes, Soller), with an overall prevalence (including fish from all localities) ( $\mathrm{n}=109$ ) of $21 \%$ and an intensity of infection of 1 nematode per fish; the total body length of infected fish caught in February, May-August and October of 1998 and 1999, was 43 to $100 \mathrm{~cm}$. Data on the prevalence and intensity of infection and the size of host fish from Italian localities were not available; the only nematode specimen obtained from cultured fish in Sicily was collected in July 2001. No philometrids were found in 8 specimens of E. marginatus bought in Portugal in October and November 1999. 
Female philometrids morphologically identical and undoubtedly conspecific with those from Epinephelus marginatus were found in the gonads of 8 greater amberjack Seriola dumerili (Risso, 1810) (Carangidae, Perciformes) (weight 10 to $20 \mathrm{~kg}$ ) from Donji Molunat Bay in Croatia (south-eastern Adriatic Sea) examined in April 1998; no data on the prevalence and intensity of infection were available.

The body of the fixed gravid nematode females (Fig. 1) from Epinephelus marginatus ( $\mathrm{n}=7$ ) (measurements of a specimen from Seriola dumerili is given in parentheses) is brown, about $25 \mathrm{~cm}(25 \mathrm{~cm})$ long and 979 to 2108 (1904) $\mu \mathrm{m}$ maximally wide, with rounded ends; the posterior part of the body is distinctly nar-
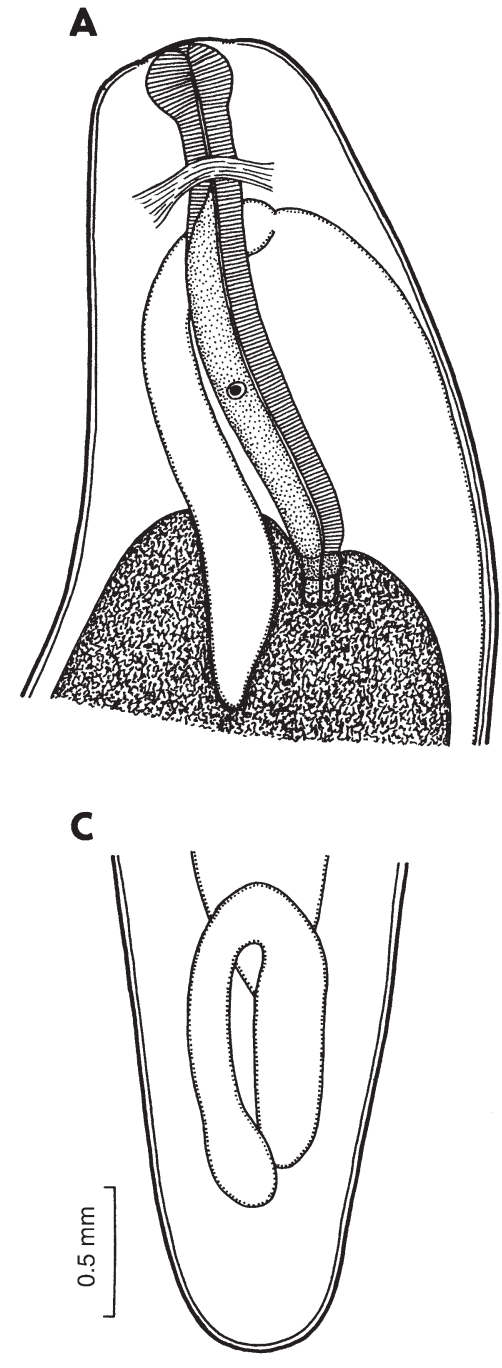

Fig. 1. Philometra lateolabracis (Yamaguti, 1935) gravid females from the ovaries of marine perciform fishes from the Mediterranean region. (A) Anterior and (B) posterior ends of a specimen from Epinephelus marginatus from Spain. (C) Posterior end (intestine end with ligament torn off from body wall and drawn back into body) and (D) anterior end of a specimen from Seriola dumerili from Croatia rower than the anterior part. The cuticle is smooth. Cephalic papillae are very small and indistinct when viewed laterally. The oesophagus is narrow, swollen near the mouth to form a distinct bulb 122 to 163 (136) $\mu \mathrm{m}$ long and 190 to 204 (204) $\mu \mathrm{m}$ wide, which is not separated from the posterior cylindrical part of the oesophagus. The overall length of the oesophagus is 1.17 to 1.54 (1.44) $\mathrm{mm}$, representing 4.7 to 6.1 (5.7)\% of the body length; the maximum width of its cylindrical part is 150 to 177 (204) $\mu \mathrm{m}$. The dorsal oesophageal gland is prominent, extending anteriorly to the level of the nerve ring and posteriorly to the small ventriculus; the gland is provided with a giant cell nucleus located in about its middle, 694 to 925 (816) $\mu \mathrm{m}$ from the anterior extremity. The ventriculus measures 41 to $54 \times 109$ to $122(54 \times$ 122) $\mu \mathrm{m}$. The nerve ring is 272 to 367 (340) $\mu \mathrm{m}$ from the anterior body end. The intestine is dark brown; the anterior end is broad and the posterior end atrophied, forming a ligament attached ventrally to the body wall, not far anterior to the posterior extremity. The posterior end of the body is rounded and no minute lateral papilla-like projections were observed on it. The vagina and the vulva are absent. Two ovaries are rather broad and are situated near the anterior and posterior ends of the body; the anterior ovary sometimes reaches up to the level of the nerve ring, the posterior ovary nearly to the body end. The uterus occupies most of the body and is filled with eggs, developing embryos and first-stage larvae; the length of the larvae is about $450 \mu \mathrm{m}$.

Even though no males of this philometrid species were found, the general morphology and measurements of the gravid females show that they can be identified as Philometra lateolabracis (Yamaguti, 1935), a species originally described from the ovaries of the marine perciform fishes Lateolabrax japonicus (Cuvier) (family Percichthyidae), Parapristipoma trilineatum (Thumberg) (Pomadasyidae) and Epinephelus akaara (Temminck et Schlegel) in Japan (Yamaguti 1935), and later reported from a variety of fishes mainly from the tropical regions of the Pacific, Indian and Atlantic Oceans (see Moravec et al. 1995). Since the males of this species have not yet 
been described from the type host in Japan and almost all subsequent records are based on females, the possibility cannot be excluded that, in fact, $P$. lateolabracis includes more than one species (Moravec et al. 1998).

López-Neyra (1951) described a new philometrid species, Sanguinofilaria jordanoi, from the females found in the ovary of Epinephelus gigas (= E. marginatus) obtained from the market in Tetuán, Morocco. The morphology and measurements of $S$. jordanoi are practically identical with those of specimens of the present material, the host species is the same, and the host fish of $S$. jordanoi probably originated from the Mediterranean Sea. Therefore, we consider $S$. jordanoi to be a junior synonym of Philometra lateolabracis. The genus Sanguinofilaria Yamaguti, 1935 was synonymized with Philometra Costa, 1845 by Rasheed (1963).

The present data suggest that Philometra lateolabracis is a widely distributed parasite of marine perciform fishes in the Mediterranean region. Since it may prove to be a significant pathogen in fish cultures in this geographical region, further, more detailed studies of this parasite are desirable. Philometrids parasitizing in the gonads of their fish hosts may cause serious damage to these organs (by sucking blood, causing atrophy of developing ova in the ovary, fibrosis of ovarian tissue, increased granulocytes and haemorrhages), thus negatively affecting the reproduction of some species of marine fishes (Moravec et al. 2002).

Acknowledgements. The authors thank Mrs. I. Husáková, Institute of Parasitology, ASCR, České Budějovice, Czech Republic, for her technical assistance with the preparation of

Editorial responsibility: Wolfgang Körting,

Hannover, Germany illustrations. This paper was partly supported by grant no. 524/03/0061 from the Grant Agency of the Czech Republic.

\section{LITERATURE CITED}

López-Neyra CR (1951) Sanguinofilaria jordanoi n. sp. (Nematoda; Filaroidea). Bol Univ Granada, Farmacia, 291-293

Moravec F, Vidal-Martínez VM, Aguirre-Macedo L (1995) Philometra margolisi n. sp. (Nematoda: Philometridae) from the gonads of the red grouper, Epinephelus morio (Pisces: Serranidae), in Mexico. Can J Fish Aquat Sci 52 (Suppl 1):161-165

Moravec F, Vidal-Martínez VM, Vargas-Vázquez J, VivasRodríguez C, González-Solís D, Mendoza-Franco E, SimáAlvárez R, Güemez-Ricalde J (1997) Helminth parasites of Epinephelus morio (Pisces: Serranidae) of the Yucatan Peninsula, southeastern Mexico. Folia Parasitol 44: 255-266

Moravec F, Nagasawa K, Ogawa K (1998) Observations on five species of philometrid nematodes from marine fishes in Japan. Syst Parasitol 40:67-80

Moravec F, Ogawa K, Suzuki M, Miyazaki K, Donai H (2002) On two species of Philometra (Nematoda, Philometridae) from the serranid fish Epinephelus septemfasciatus in Japan. Acta Parasitol 47:34-40

Ramachandra P (1975) Philometra cephalus sp. n. infecting the gonads of the striped mullet, Mugil cephalus L. from the Arabian coast of Kerala, India, with a note on its pathology. Zool Anz 194:140-144

Rasheed S (1963) A revision of the genus Philometra Costa, 1845. J Helminthol 37:89-130

Sakaguchi S, Yamagata Y, Goto M (1987) Reidentification of Philometra parasitic in Red Sea bream. Bull Nat Res Inst Aquacult 12:69-72 (in Japanese with English summary)

Yamaguti S (1935) Studies on the helminth fauna of Japan. Part 9. I. Nematodes of fishes. Jpn J Zool 6:337-386

Submitted: April 12, 2002; Accepted: December 2, 2002

Proofs received from author(s): January 23, 2003 